\title{
Forecasting the Potential Economic Impact of Ecological Restoration of Illegal Mines on Employment and Household Income in Ghana
}

\author{
Emmanuel Owusu $^{1 *} \quad$ Li Fanglin ${ }^{2} \quad$ Nelly Ataawomba Afuubi ${ }^{3} \quad$ Emmanuel Sogbou Kenne $^{4}$ \\ 1.School of Finance and Economics, Jiangsu University, 301 Xuefu Road, Jingkou District, Zhenjiang, Jiangsu, \\ China \\ 2.School of Statistics, Jiangsu University, 301 Xuefu Road, Jingkou District, Zhenjiang, Jiangsu, China \\ 3.School of Finance and Economics, Jiangsu University, 301 Xuefu Road, Jingkou District, Zhenjiang, Jiangsu, \\ China \\ 4.School of Transporation, East China Jiaotong University, 808 Shuanggang New Development Zone, Nanchang \\ City, Jiangxi Province, 330013, China
}

\begin{abstract}
Ghana has a long-standing problem of illegal mining that has destroyed the environment. The country is taking steps to curb illegal mining and restore disturbed lands. The research used a social economic impact assessment in terms of outputs of a project to estimate the number of employments to be created and household income produced for communities where ecological restoration takes place. The research collected secondary data on the cost and number of individuals employed for a 1-hectare ecological restoration projects from 5 sites in AGA Obuasi mines, AGA Iduapriem mines and Newmont Ghana Gold Limited. The average number of employed individuals was 27 and average income earned associated with these projects was $\$ 2,508$. From the research, projections made to meet the country's target of restoring 23,800,000 hectares were $652,000,000$ jobs and $\$ 48,984,000,000$ in income. Thus, ecological restoration can boost the economy of the country, especially local economies and at the same time increase the country's ecological integrity.
\end{abstract}

Keywords: Ecological restoration, illegal mining, job creation, Household income, local economy

DOI: $10.7176 / \mathrm{JESD} / 11-22-07$

Publication date: November $30^{\text {th }} 2020$

\section{Introduction}

Managing natural resources in an environment is a major question researcher have delved into, owing to the connected relationship of components in the environment. Indeed, diverse methods have been designed and applied to provide sound and sustainable environmental management options.

Mining entities both legal and illegal should be responsible for restoring disturbed lands during their operations. As part of being a responsible mining entity, restoration plans are to be designed to bring disturbed lands back to their previous state or even a better one.

Mining entities need to be responsible in their operations and restoring lands involve steps that continue to the point of decommissioning where there is not any likelihood of a reclaimed or restored land having some negative impacts on communities surrounding them. The safe, environmental, and social risks arising from badly conducted mine closure can result in significant liabilities for mining companies. For communities, closure can cause severe distress because of the threat of economic and social collapse. In the case of illegal mining entities who are not accountable for the environmental damages in the course of their operations, the disturbed lands from their operation could led to enormous negative impact on the economy, environment and social integrity of the community and country in general. Abandoned mines may result in large clean-up costs and closure liabilities for governments (World Bank, 2002). Illegal mining popularly referred to as "Galamsey" which was derived from the phrase "Gather them and sell" is a social menace causing havoc to many natural ecosystems in Ghana. According to Ghana Minerals Commission, there are about 20,000 to 50,000 illegal miners as of 2013 and their operations are increasing at an exponential rate. These operations have lasted over decades until it was recently banned by Government in 2017. There are no doubts these operations provide some sources of employment in Ghana but needs to be regulated by government to prevent it from destroying the society and environment as reported by The Africa Report in 2013. The Government of Ghana has placed a ban on illegal mining, and this has led to many individuals becoming unemployed. As the ban seeks to halt all operations and regulate illegal mining operation the government also plans to make provisions for the reclamation or restoration of these illegal mining sites which when left unattended to, will be disastrous to communities surrounding it. As the government intends to restore these illegal mining sites this research seeks to analyze the economic impact of ecological restoration of these illegal mining sites in terms of job creation and income in Ghana. 


\section{Ecological Restoration}

The Society for Ecological Restoration broadly describes restoration as "the process of assisting the recovery of an ecosystem that has been degraded, damaged, or destroyed." Ecological restoration has traditionally been defined as an act of returning a system to an original state, and is distinguished from rehabilitation, which is more broadly defined as any act to improve the degraded state of the ecosystem. Intact or "original" ecosystems will have both high structural and functional attributes compared to degraded systems. While 'remediation,' 'reclamation,' 'enhancement,' and 'mitigation' are also activities performed on degraded ecosystems, the outcome of these activities is an alternative state or partial recovery of an original state. For our purposes, we define restoration as any combination of activities intended to result in ecological uplift, improve ecosystem health, and result in a functioning ecosystem that provides a suite of ecosystem services (i.e. the beneficial functions of ecological systems according to World Resources Institute, 2005. These activities may include conservation activities - such as the purchase of conservation easements, land acquisition, or transfer of water rights only when such investments are a part of a larger restoration effort. By defining the restoration economy around the industries that contribute to these efforts, we inductively define restoration as being comprised of the set of economic activities that contribute to restoration, from project planning, engineering and legal services, to intermediate suppliers of inputs, to on-the-ground earthmoving, forestry, and landscaping firms that contribute to the ecological restoration process.

During mining there are many different activities that lead to the destruction of the ecosystem. They include clearing large swathes of vegetation, destroying of topsoil and subsoil to get to the raw material. During the process of mining processed water referred to as tailings is stacked in a dam or adjacent farmland which is typical of galamsey. The tailings produced by mining activities need a large area, referred to as the tailings pool, for stacking. With the disposal of the tailings, the original ecosystem of the tailings pool is seriously affected (Chen et al., 2016). In Ghana, most areas blessed with gold deposit have been destroyed by galamsey and the government plans to restore the lands to a productive use like farming or forestry.

\subsection{Justification of Ecological restoration}

Nature is beautiful and we should value, preserve, and restore the beauty of the Earth, as we would for a beautiful or historical building or painting. I, my children, and grandchildren deserve to see everything that nature has to offer, not just the remains of overused and abused ecosystems. Even though dinosaurs are extinct, what would you give to see one alive? Extinction eliminates the potential for people to tap the genetic reservoirs of life. Nearly all our foods, medicines and fibers come directly from, or are synthetically patterned after natural materials. Providing future generations with the means of life, including the cure for disease, requires the preservation and restoration of ecosystems. If nature breaks down, then human survival is threatened, because we cannot substitute human labor and capital for "free" ecosystem services, such as decomposition, pollination, oxygen recycling, climate regulation, etc. Why would we not intervene in nature if it meant saving ourselves? The close relationship that develops between people and the land they restore or manage is mutually beneficial. People restore their connection to nature and benignly transform their attitudes towards it, and nature is enhanced as restoration takes place. Nature has an inherent right to exist. As human society has evolved, rights have been granted to an ever-widening circle beyond the individual, extended in recent times to include trees, birds, flowers and all of nature. People have no right to destroy nature. Instead people

should do whatever they can to preserve and restore ecosystems to their most natural state. We define ecological restoration as a practical management strategy that restores ecological processes to maintain ecosystem composition, structure, and function. Successful restoration requires a full understanding of the ecological deficiencies in the ecosystem, a defined course of scientific study through experimental management, and the development of a program for carrying out restoration. Although, our definition of restoration is humancentered, because restorations occur to satisfy people, our intent is to design restoration strategies that ultimately minimize human intervention. Restoration and safeguarding of ecosystems that provide ecosystem services (including degraded land) have been recognized by the international community as means to enhance and maintain biodiversity and ecosystem services, as articulated in Aichi Targets 14and 15 of the Strategic Plan for Biodiversity 2011-2020agreed by parties to the Convention on Biological Diversity in October 2010 (CBD 2010). As investments in implementing the Strategic Plan accelerate, governments need information on the relative costs and benefits of actions, including ecological restoration, needed to achieve these targets (CBD 2012). The ecologist must acknowledge the dominance of human values in setting goals for restorations. We believe the goal of ecological restoration is the establishment of sustainable, productive ecosystems that benefit humans. Analysis of the costs of restoration and its benefits is very different from short-term cost-benefit analyses for commodity production because the latter often does not factor in long-term loss ecological changes and ecosystem deterioration.

Several political actors, including states and international organizations, such as United Nations Environment Programme, have made declaratory commitment to engage in ecological restoration (Nelleman and 
Corcoran 2010), although implementation activities typically take place at the regional and especially the local levels. Restoration is seen as offering many benefits, including helping to address global environmental change. Climate change mitigation and adaptation policy, for example, is increasingly relying upon restoration through reforestation for carbon sequestration or restoring wetlands for flood protection. It is also used as a way of safeguarding the provision of ecosystem services. Restoration is stressed as a means of achieving the 2020 Biodiversity Targets, the so-called Aichi Targets, including by the European Union (EU; CEC 2011). In addition, it is increasingly seen as important in agricultural policy and in efforts to improve food security, and as a tool for implementing various resource specific policies, for example, the EU Water Framework Directive, whose target is to restore surface waters and ground waters to 'good ecological status' (WFD EC2000/60). Similarly, restoration is widely used a compensation tool in planning decisions to compensate for disruptions to the visual or cultural qualities of landscapes, often bringing in elements of historic practices and a community's sense of place. Restoration projects can target many different ecological systems or landscapes and be conducted both in urban (Platt 2006) and rural areas. Such activities can occur across a variety of scales, from limited and highly localized experiments and hesitant trials, to remediation of industrial, quarrying, or mining sites, to what are best described as 'mega projects', such as the Kissimmee River restoration initiative in central Florida (Whalen et al. 2002), restoration of the prairies in the USA (Ryan 2000), or contemporary water management initiatives in the Netherlands (Drenthen 2009). Projects can also involve the deliberate reintroduction of species that have been lost or made existent at the local level because of changes in land use and other development pressures. Wolf reintroduction policies form a typical example, restoration initiatives that have led to controversies in both Scandinavia and in North America, not least because of local concerns about potential loss of livestock (Gross 2008). River restoration is another focus of project attention, involving the removal of dams, river remeandering and re bouldering (for example, in Sweden, see Lejon et al. 2009), 'daylighting' of culverted rivers, or ecological remediation of urban river banks (for example, in the UK, see Eden and Tunstall 2006).

\subsection{Cost and Benefits of ecological restoration}

Although some individual companies may contribute to carbon compensation schemes or support individual restoration projects, a wider global initiative (consortium, mechanism) to engage business is urgently needed, because the business community has many of the essential capabilities required for success, including a hands-on approach, the ability to mobilize local communities, and the resources to finance projects. Several studies have found a significant profit motive to funding restoration activities. For example, an IUCN analysis (IUCN) shows that, once restored, 150 million ha would pump more than US\$80 billion into national and global economies and close the climate change "emissions gap" by $11 \%-17 \%$. Based on TEEB data (2009) a mean investment per hectare of US\$2390 is needed; to restore 200 million ha, US\$478 billion, or about EUR450 billion, is needed over 20 years. That is approximately US\$24 billion or EUR 22.5 billion a year. De Groot et al. (2013) find that, even in a worst-case scenario (i.e., discount rate of $8 \%, 100 \%$ of the maximum cost, and a restoration benefit of $30 \%$ of the total economic value), investing in restoration still breaks even or provides a financial profit (in total economic value) in six ecosystem types. There are ample evidence that public and private investments driven by federal regulations stimulate economic output and employment in restoration-related industries, contributing growth and jobs to the national economy in the short term, as well as long-term value and cost savings. To produce economic output, firms purchase input materials and services from other sectors of the economy (e.g., construction equipment, tools, computers, and specialized services). Thus, other sectors are stimulated indirectly from the direct sales of restoration firms (indirect impact). Finally, workers employed directly by restorationrelated firms and indirectly in other sectors that sell inputs to restoration firms spend earnings on goods and services needed to support their households (induced impacts). Restoration is not limited to any single industry; it comprises a mixture of industries. Assessing the direct, indirect, and induced effects requires constructing a custom input-output model. We did this by weighting multipliers from multiple industries by their relative contribution to the restoration program or project of interest.

\section{METHODOLOGY}

\subsection{Study Area}

Bekwai Municipal Assembly (BMA) is one of the 27 districts in the Ashanti Region established under Legislative Instrument (L.I. 1906, 2007). Until recently the Bekwai Municipality was part of the Amansie East District made up of the Bekwai and Bosome-Freho Constituencies. It is in the southern part of Ashanti Region. It shares boundaries with Bosomtwe District in the north, Adansi-North in the south, Bosome-Freho District to the East and Amansie-Central and Amansie -west to the west. The Municipality lies within latitude $6^{\circ} 00^{\prime} \mathrm{N} 6^{\circ} 30^{\prime} \mathrm{N}$ and Longitudes $1^{\circ} 00 \mathrm{~W}$ and $1^{\circ} 35 \mathrm{~W}$. It covers a total land area of about $633 \mathrm{sqkm}$.

Amansie East (Bekwai) is an area endowed with gold deposits in most areas. The area has many galamsey activities going on. The entire District is rich in gold deposits and mining has emerged as the most important economic activity in the communities. Mining companies have acquired almost all the remaining land area in the 
District for either prospecting or actual mining (Ministry of Food and Agriculture 2010). Apart from the companies with large concessions in the district, there are other interested parties in the mining industry. The activities of small-scale miners, mostly galamsey operators who employ very crude methods to mine for gold are continually increasing in the district. The activities of these various groups are not properly regulated and not well organized as part of a total package development effort even though it goes a long way to alleviate the poverty situation in the district (MVP 2008). AngloGold Ashanti mining company mines on lands owned by the municipality. The company tries its best to employ people from the area but as usual cannot employ everyone. Most abled young boys and girls indulge in galamsey to provide for their families. The rate of deforestation and land degradation is high and collectively has led to government's bold step to ban this illegal activity.

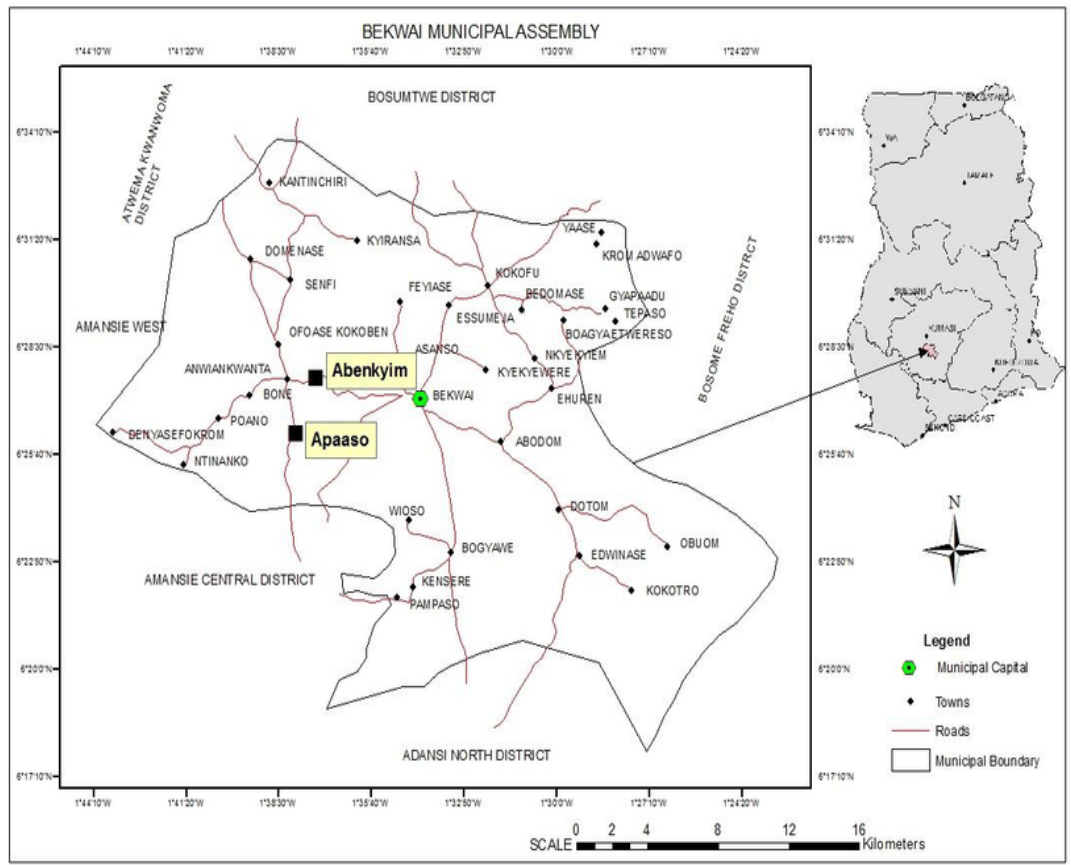

Fig.1 Map of Ghana showing Bekwai

\subsection{Data Collection}

Secondary data refers to the use of pre-existing data for a topic (Hanson, 2012). This study also dwelled on data from AngloGold Ashanti Obuasi mines, AngloGold Ashanti Iduapriem mines and Newmont Ghana Gold Limited, reports, field sheet, newspapers and other media that provide commentary on illegal small-scale mining in Ghana.

\section{RESULTS}

The average number of people employed for a 1-hectare ecological restoration project was 27.4 and the average total income was $\$ 2,058.00$. Details are presented in Figure 2. Projections made to meet a 23,800,000-hectare target by the country shows that ecological restoration can provide $652,000,000$ jobs and provide incomes worth $\$ 489,804,000,000$ as shown on Figure 3. Ecological restoration will impact positively on the economy by adding jobs and increasing household incomes within the local economy and surrounding communities. Indirect jobs can also be created in areas like tree nursery businesses, soil testing laboratories and others. The target set by government for restoring disturbed lands is ambitious but with the set-up of favorable business environment will attract private investment in this sector which will help government achieve its targets. Agriculture has accounted for a larger part of the economy of Bekwai Municipal Area and with galamsey activities increasing exponentially over the period of times farmlands have been destroyed and agricultural activities for that matter has been dwindling. The ban on galamsey has impacted people's lives and economic activities in general. According to Interview conducted during the research, Mohammed Kololo, a butcher in Bekwai, the sale of meat to galamsey miners, specifically Chinese miners had fallen drastically over the period of times as galamsey has been banned. (field sheet, 2019). According to Adjei Samuel, 2012, Galamsey have a direct impact on trading activities, increases the disposal income not only for the illegal miners but a large portion of the community especially those into trading of goods and rendering of services. It creates an avenue for people to get some form of employment and earn huge sums of money. It also has an impact in their social life but also its negative impacts outweigh the positives. According to the research, ecological restoration operations are expected to add 
on average 27 jobs per hectare (both temporal and permanent) and (skilled and unskilled) to the local economy. D. Verardo, and D. Dokken (1998), Ecological restorations projects need community participations and as such believed to employ most of the people from the community in which the project takes place. According to an individual involved in ecological restoration on Adubriem ecological restoration project in AGA, on an average could earn \$20.00-\$200.00/per hectare depending on the sector of the project they took part in. For an example, a woman by name Gladys said she was involved in grassing and tree planting on Adubriem reclamation project. They were a group of 5 people who grassed and planted trees on a 2-hectare portion of Adubriem reclamation project site and earned $\$ 20$ per day for 10 days. (field data collection).

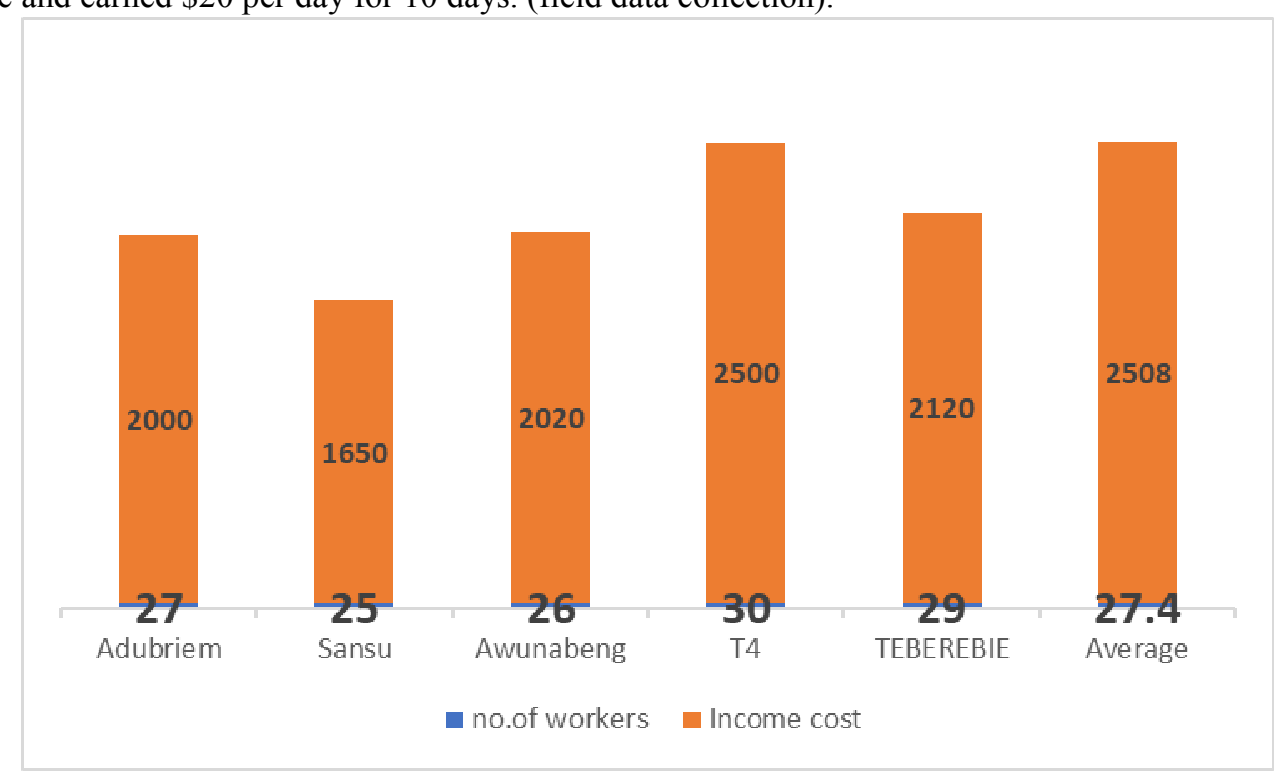

Figure 2. Average employment and cost of a 1-hectare ecological restoration project for forestry.

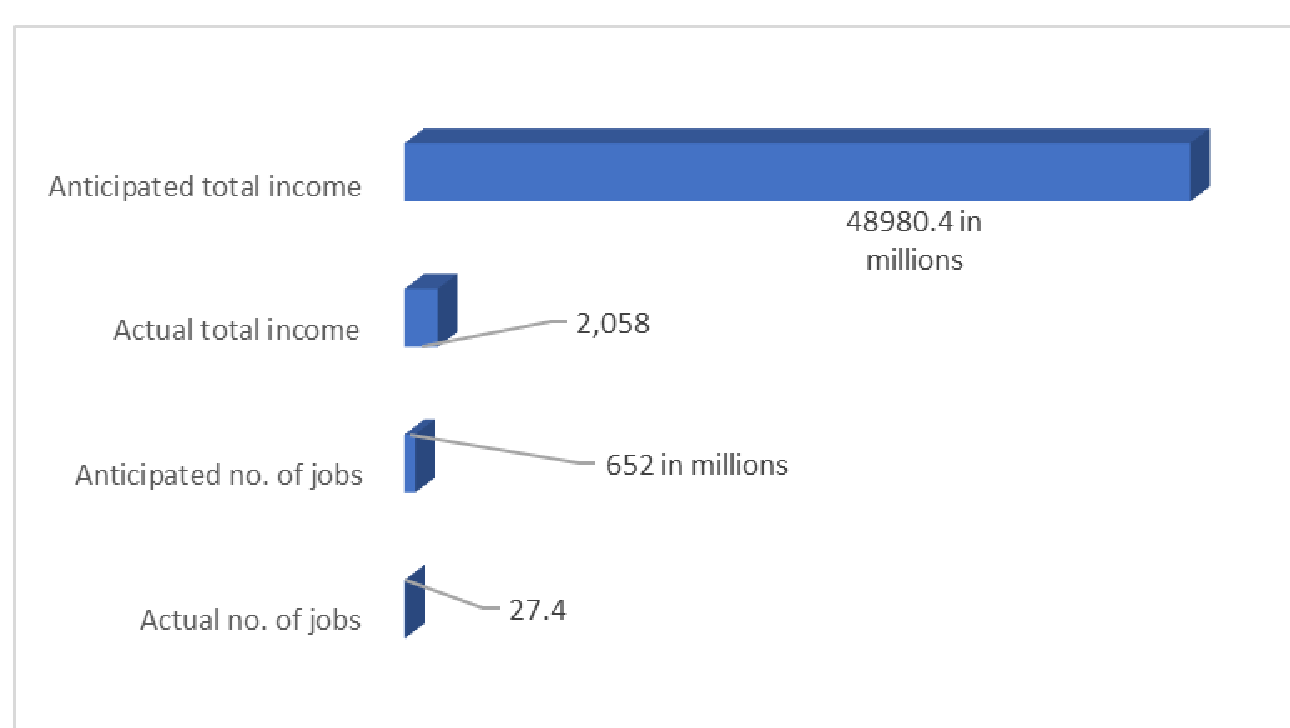

Figure 3. Job and Income (\$) projections to meet ecological restoration targets (for forestry) by Ghana

\section{CONCLUSION}

Ecological restoration is an important development tool that can bring potential economic gains. These projects massively involve the use of community members which likely makes the project sustainable. This new area of business is not favourable to the private sector due to profitability hence government needs to set policies like tax exemptions, incentives and other sustainable and green policies that attract businesses into this area. The research also provides recommendation for the assessment of the cost and benefits associated with ecological restoration to provide government with enough data on ecological restoration projects in Ghana.

\section{Funding Institution}

The research work was fully supported by the National Natural Science Foundation of China and the grant 
number 71503105 .

\section{References}

Adams, W. M., M. R. Perrow, and A. Carpenter. (2005). Perceptions of river managers of institutional constraints on floodplain restoration in the UK. Journal of environmental planning and management 48(6):877-889.

Apfelbaum, S.I., and A. Haney. (1989). Management of degraded oak savanna remnants in the upper Midwest: Preliminary results from three years of study. Pages 290-291 in proceedings of the society for ecological restoration and management, Oakland, California, USA.

Apfelbaum, S.I., and C. Sams. (1987). Ecology and control of reed canary grass (phalarisarundinacea l.). Natural areas Journal 7(2):69-74.

Ariel A., Andrea G. and Tamar D. (2017). Inter basin water transfer for the rehabilitation of a transboundary Mediterranean stream. Journal of environmental management, 202, (276), (2017). Australian minerals and energy industries. UNSW press \& Ameef, Sydney, 227-264.

Bash, J. S., and Ryan C.M. (2002). Stream restoration and enhancement projects: is anyone monitoring? Environmental management 29(6):877-885.

Bernhardt, E. S., Sudduth E. B., Palmer M. A., (2007). Restoring rivers one reach at a time: results from a survey of U.S. River restoration practitioners. Restoration ecology 15(3):482-493.

Breckenridge, L. P. (2006). Special challenges of transboundary coordination in restoring freshwater ecosystems. Pacific McGeorge global business \& development law journal 19(1):13-32.

Buijs, A. E. (2009). Public support for river restoration. A mixed-method study into residents' support for and framing of river management and ecological restoration in the Dutch floodplains. Journal of environmental management 90(8):2680-2689.

Callicot, J. B., and Nelson M., (1989). The great new wilderness debate. Georgia university press, Athens, Georgia, USA.

Clewell, A. F., and Aronsson J. 2007. Ecological restoration: principles, values, and structure of an emerging profession. Island press, Washington, D.C., USA.

Baker, S.R., Gardener, J.H., and Ward, S.C. (1995), Bauxite mining environment management and rehabilitation practices in Western Australia. In Proceedings of the Australian Institute of Mining and Metallurgy, World's Best Practice in Mining and Mineral Processing Conference. Sydney, Australia, 17-18 May 1995.

Bell, L.C. (1996). Rehabilitation of disturbed land in environmental management.

Bradshaw, A.D. (1984), Land restoration: Now and in the future. SER. B, 223: 1-23.

Bradshaw, A.D. (1999), The importance of nitrogen in the remediation of degraded land.

Bradshaw, A.D. (1990), The reclamation of derelict land and the ecology of ecosystems.

Brundrett, M., Abbott, L., Jasper, D., Ashwath, N., Malajczuk, N. \& Bougher, N.(1992b), Mycorrhizal associations of plants in disturbed and undisturbed soils of the alligator rivers region: part ii, preliminary report progress report, September 1992.

Bullock J, Aronson J, Newton A, Pywell R, Rey-benayas J. (2011). Restoration of ecosystem services and biodiversity: Conflicts and opportunities. Trends in ecology \& evolution 26:541-549.

Bunso Cocoa College (1987). A guide to cocoa cultivation, a handbook for practical work, 35p.

Cairns, Jr., J. (1993), Ecological restoration: Maintaining per capita ecosystem services while the human population grows to ten billion.

Central intelligence agency (2006). World fact book: Uganda, people. Accessed 26 April 2006.

Coenen, F. H. J. M., Huitema, D. and O’toole L. J. (1998). Participation and environment. Page 126.

Drenthen, M. (2009). Ecological restoration and place attachment: Emplacing non-places?

Environmental values 18:285-312.

Eden, S., and Tunstall. S. (2006). Ecological versus social restoration? How urban river restoration challenges but also fails to challenge the science-policy nexus in the United Kingdom. Environment and planning c: government and policy 24:661-680.

Ekker, T. (2004). The idea of wilderness. International Journal of wilderness 10(1):15-17.

Elliot, R. (1982). Faking nature. Inquiry 25(1):81-93.

Ecosystem marketplace 2012. State of the forest carbon markets 2012: Leveraging the landscape.

Ecosystems and human well-being: biodiversity synthesis," (report, millennium ecosystem assessment, 2005.

Fischer, f. (1998). Beyond empiricism: Policy inquiry in post positivist perspective. Policy studies 26(1):129-146. 


\section{APPENDIX}

Table 1 Number of jobs and cost incurred for Adubriem Mine waste Dump

\begin{tabular}{|c|c|c|}
\hline \multicolumn{3}{|c|}{ ADUBRIEM MINE WASTE DUMP } \\
\hline Activities & No. of People & cost $(\$) /$ time \\
\hline engineering works & 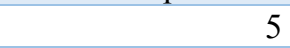 & 500 \\
\hline clean up and contamination & 5 & 500 \\
\hline topsoil spreading & 1 & 200 \\
\hline seed collection and tree nursery management & 5 & 200 \\
\hline Grassing and planting & 7 & 200 \\
\hline maintenance eg thinning & 2 & 200 \\
\hline monitoring & 2 & 200 \\
\hline TOTAL & 27 & 2000 \\
\hline
\end{tabular}

Table 2. Number of jobs and cost incurred for Sansu Mine waste Dump

\begin{tabular}{|c|c|c|}
\hline \multicolumn{3}{|c|}{ SANSU MINE WASTE DUMP } \\
\hline Activities & No. of People & cost $(\$) /$ time \\
\hline engineering works & 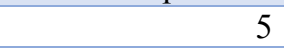 & 700 \\
\hline clean up and contamination (phytoremediation) & 7 & 200 \\
\hline top soil spreading & 1 & 250 \\
\hline seed collection and tree nursery management & 0 & 0 \\
\hline Grassing and planting & 10 & 300 \\
\hline maintenance eg thinning & 2 & 200 \\
\hline monitoring & 0 & 0 \\
\hline TOTAL & 25 & 1650 \\
\hline
\end{tabular}

Table 3. Number of jobs and cost incurred for Awunabeng Mine waste Dump

\begin{tabular}{|l|r|r|}
\hline & AWUNABENG MINE WASTE DUMP & Cost (\$)/time \\
\hline Activities & No. of People & 600 \\
\hline engineering works & 7 & 500 \\
\hline clean up and contamination & 5 & 300 \\
\hline Hydroseeding & 2 & 220 \\
\hline Grassing and planting & 8 & 200 \\
\hline maintenance eg thinning & 2 & 200 \\
\hline monitoring & 2 & $\mathbf{2 0 2 0}$ \\
\hline TOTAL & $\mathbf{2 6}$ & 2 \\
\hline
\end{tabular}

Table 4. Number of jobs and cost incurred for T4 Mine site

\begin{tabular}{|l|r|r|}
\hline Activities & T4 MINE SITE & Cost (\$)/time \\
\hline engineering works & No. People & 5 \\
\hline Erosion controls & 5 & 500 \\
\hline clean up and contamination (phytoremediation) & 5 & 500 \\
\hline top soil spreading & 1 & 500 \\
\hline seed collection and tree nursery management & 0 & 200 \\
\hline Grassing and planting & 10 & 0 \\
\hline maintenance eg thinning & 2 & 400 \\
\hline monitoring & 2 & 200 \\
\hline TOTAL & $\mathbf{3 0}$ & 200 \\
\hline
\end{tabular}


Table 5. Number of jobs and cost incurred for Teberebie Mine waste Dump

\begin{tabular}{|l|r|r|}
\hline \multicolumn{1}{|c|}{ TEBEREBIE MINE WASTE DUMP } & \\
\hline Activities & No. of People & Cost (\$)/time \\
\hline engineering works & & 7 \\
\hline clean up and contamination & 5 & 600 \\
\hline top soil spreading & 1 & 500 \\
\hline seed collection and tree nursery management & 4 & 200 \\
\hline Grassing and planting & 8 & 200 \\
\hline maintenance eg thinning & 2 & 220 \\
\hline monitoring & 2 & 200 \\
\hline TOTAL & $\mathbf{2 9}$ & 200 \\
\hline
\end{tabular}

